\title{
ANAESTHESIA AND RECENT MYOCARDIAL INFARCTION
}

\author{
D. V. Catton, M.D. ${ }^{*}$
}

A FRACTURED HIP in an elderly patient is still a frequent cause of death. The initial shock, together with early development of pulmonary, cardiovascular, renal, or skin complications, often leads to death. Internal fixation of the fracture within the first few days after injury permits early mobilization and thus avoids the dangers of prolonged recumbency and immobility in these elderly patients. Prior to the introduction of the Smith-Petersen nail, the use of a Whitman plaster cast secured union in about 40 per cent of cases with a mortality rate of about 25 per cent. With the Smith-Petersen nail, union can be expected in 75-80 per cent of cases with a mortality rate of about 10 per cent. ${ }^{1}$

In most patients with heart disease the risk of a carefully administered anaesthetic (with avoidance of hypotension, hypoxia, and hypercarbia) is little greater than in normal patients. However, the situation is markedly changed in patients who have suffered a recent myocardial infarction. In one series ${ }^{2}$ of 517 patients with coronary heart disease who underwent surgical intervention, the mortality rate was 2.9 per cent. In a comparable group of 4154 patients without clinical evidence of coronary heart disease the operative mortality rate was 2.0 per cent. Within the group of 517 with coronary heart disease 11 were operated upon, of necessity, during the acute phase of their myocardial pathology (within two days to seven weeks) and two of these died. Thus the mortality rate in the group with recent myocardial infarctions was 18.2 per cent. Elective surgery and anaesthesia following myocardial infarction should be postponed for some time. The interval recommended varies with different authors from at least a month or two, ${ }^{3}$ a period of two to three months, ${ }^{4}$ to at least three months. ${ }^{2}$ In the presence of an acute myocardial infarction, surgical and anaesthetic stress is liable to lead to rupture of the infarcted area and a fatal cardiac tamponade. (As little as 200 to $300 \mathrm{ml}$. of blood in the pericardial sac may be sufficient to cause death.5)

The pathology of the structural changes in the heart muscle following an infarction has been described by Robins. ${ }^{\text {i }}$ Gross changes are not seen if the patient lives less than 12 hours. In 18 to 24 hours the area of necrosis is anaemic, without alteration in consistency. Between the second and fourth days the area becomes paler and more defined. Between the fourth and tenth days the infarct varies from yellow-grey to bright yellow, with highly vascularized margins. The infarcted area is now considerably more soft and flabby than the surrounding uninvolved myocardium. Beginning at the 10 th day, progressive fibrous replacement of the necrotic zone commences, first evident at the margins of the infarct. Total fibrous scarring has usually accurred by about the end of the sixth week. Microscopic changes within the first 18 hpurs consist of coagulation necrosis.

${ }^{*}$ St. Joseph's Hospital, London, Ontario. 
After 24 hoưrs some interstitial oedema, haemorrhage, and scant neutrophilic infiltration may be present. From 24 to 72 hours coagulation necrosis of the muscle fibres is well developed, but the cell outlines remain. Between 4 and 10 days the muscular protoplasm becomes granular and fragmented. Fat stains demonstrate large amounts of sudanophilic material. The neutrophilic infiltrate becomes mixed with macrophages. At the margins fibroblastic and capillary perforation with beginning organization is seen. From the 14th day on there is progressive resorption of the necrotic sarcoplasm and ingrowth of granulation tissue. Over the next four to six weeks total organization occurs, well vascularized at first, and later relatively avascular and transformed into a collagenous connective tissue. Progressive hyalinization occurs over several months and calcification or even ossification may occur.

It would appear most likely that a myocardial infarction ruptures within the first two weeks. At this time the infarct is necrotic, soft, and has the least reparative fibrous strength. The rupture usually occurs as an irregular linear tract traversing the myocardial wall and terminating in a small defect in the epicardium.

The unfortunate combination of a fractured hip in a person suffering from a recent myocardial infarction is the subject of the following case report.

Mrs. L. P., a 76-year-old white female, was admitted to St. Joseph's Hospital on August 5, 1962. She complained of pain in her left hip following a fall two days earlier, and radiographs revealed a subcapital fracture of the left femur. She had been under treatment in another hospital for a suspected myocardial infarction on July 29, 1962. Her past history included hypertensive cardiovascular disease, a myocardial infarction in 1960 and marked exertional chest pain with dyspnoea, leading up to her recent suspected myocardial infarction. The physical findings consisted of a painful left hip, bilateral basal rales with an otherwise clear chest, a soft apical systolic murmur, and blood pressure 140/82 mm. $\mathrm{Hg}$ with a regular pulse of 84 beats per minute. Her Hb. was 13 grams per cent and the N.P.N. normal. The white blood count was elevated to 17,000 per cu. $\mathrm{mm}$. The electrocardiogram (Fig. 1) was interpreted as showing sclerotic myocardial pathology without definite evidence of a recent infarction.

She was observed for 36 hours and treated with digitalis and diuretics. After premedication with meperidine $25 \mathrm{mg}$., promethazine $25 \mathrm{mg}$., and atropine grains $1 / 150$, she was taken to the operating room on August 7, 1962. At 10:05 a.m. anaesthesia was induced with thiopentone ( 2.5 per cent) $100 \mathrm{mg}$. followed by succinylcholine $40 \mathrm{mg}$. After oxygen inflation the larynx and trachea were sprayed with 4 per cent lignocaine and a No. 10 orotracheal tube introduced. Anaesthesia was maintained with nitrous oxide, oxygen, halothane, and intermittent meperidine (total dose of $35 \mathrm{mg}$.). During the application of a SmithPetersen nail and side plate, her blood pressure remained between 110 and $140 \mathrm{~mm}$. systolic, the pulse rate was steady at 100 per minute, and blood loss was small. She ras returned to the recovery room at 11:45 a.m. in apparently satisfactory condition (blood pressure 140/80 mm. Hg. and pulse rate 120). At 12 p.m. she was still unconscious but satisfactory (blood pressure 136/90 $\mathrm{mm}$. $\mathrm{Hg}$. and pulse rate 108). At 12:08 p.m. she suddenly became cyanotic, pulseless, apnoeic, and without blood pressure. At 12:15 p.m., after an attempt at resus- 


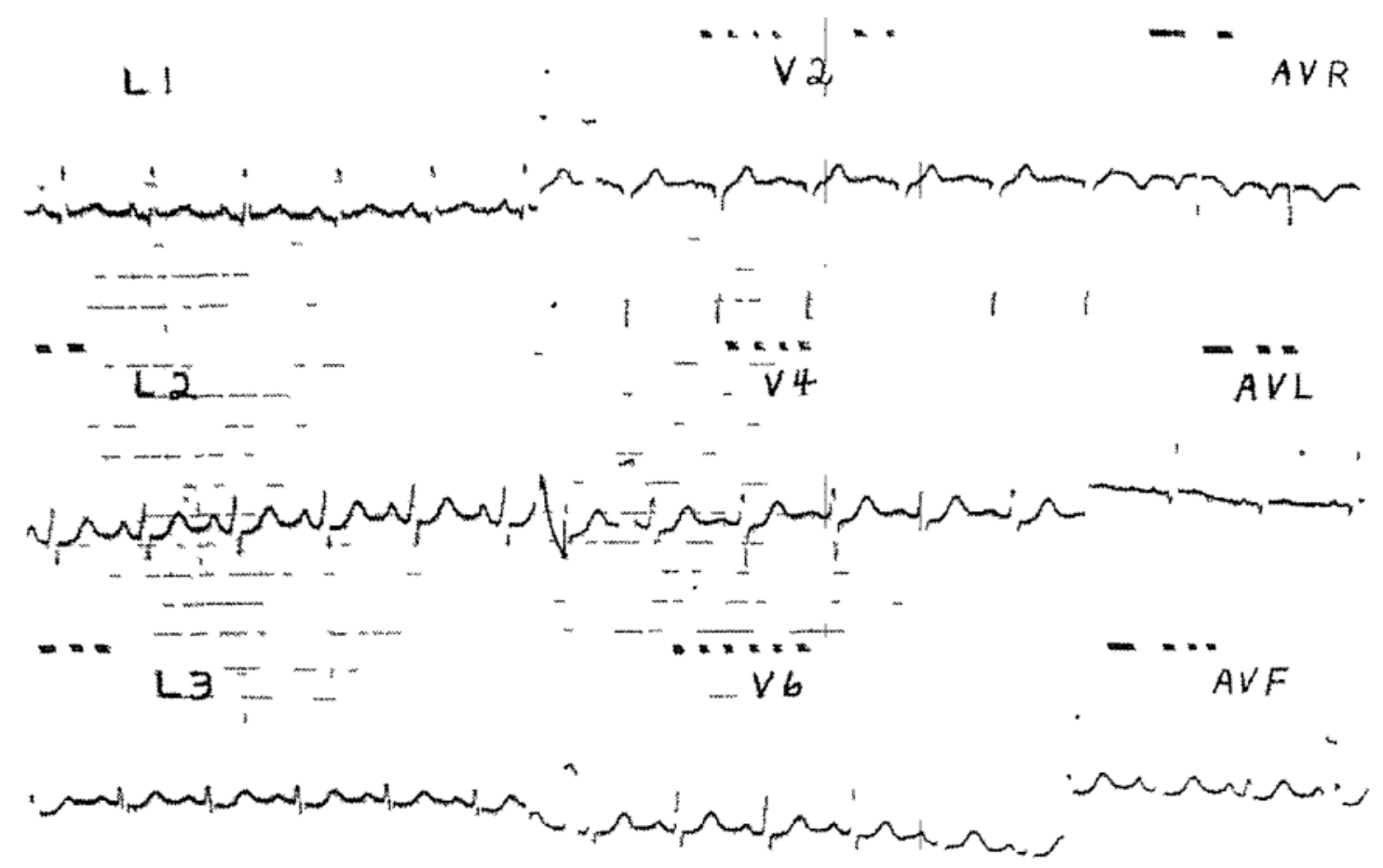

Figure 1 Electrocardıgram on August| 6, 1962.

citation using manual ventrlation, vasopressors, and closed-chest massage she was pronounced dead.

At autopsy the pericardial sac contained about 280 grams of fresh blood clot and a rent was seen on the anterior surface of the left ventricle (Fig. 2). The heart weighed 350 grams and the ventricles were not hypertrophed. On the anterior wall of the left ventricle there was an extensive recent anteroseptal infarct (Fig. 3) and areas of haemorrhage were seen which communicated with haemorrhage in the epicardial fat running alongside the descending branch of the left coronary artery. A rupture was present in the serosal aspect of the pericardium and blood issued from it. An old healed infarct was present in the posterior wall of the left ventricle. Extensive coronary atheroma was seen. A microscopic section through the recent infarct showed extensive necrosis affecting most of the thickness of the ventricular wall and with an early zone of absorption. Leucocytic response was intense and necrotic leucocytic material was present in the depths of the necrotic zone. Extensive haemorrhage was present in the myocardium. The age of the recent infarct was estimated at five to seven days.

\section{Discussion}

In caring for the ever increasing geriatric population, special problems are presented to the anaesthetist and surgeon. The presence of two potentially lethal disease processes in the same patient is not a rarity in this age group. In the case described above, after careful preoperative assessment, it was felt in the 


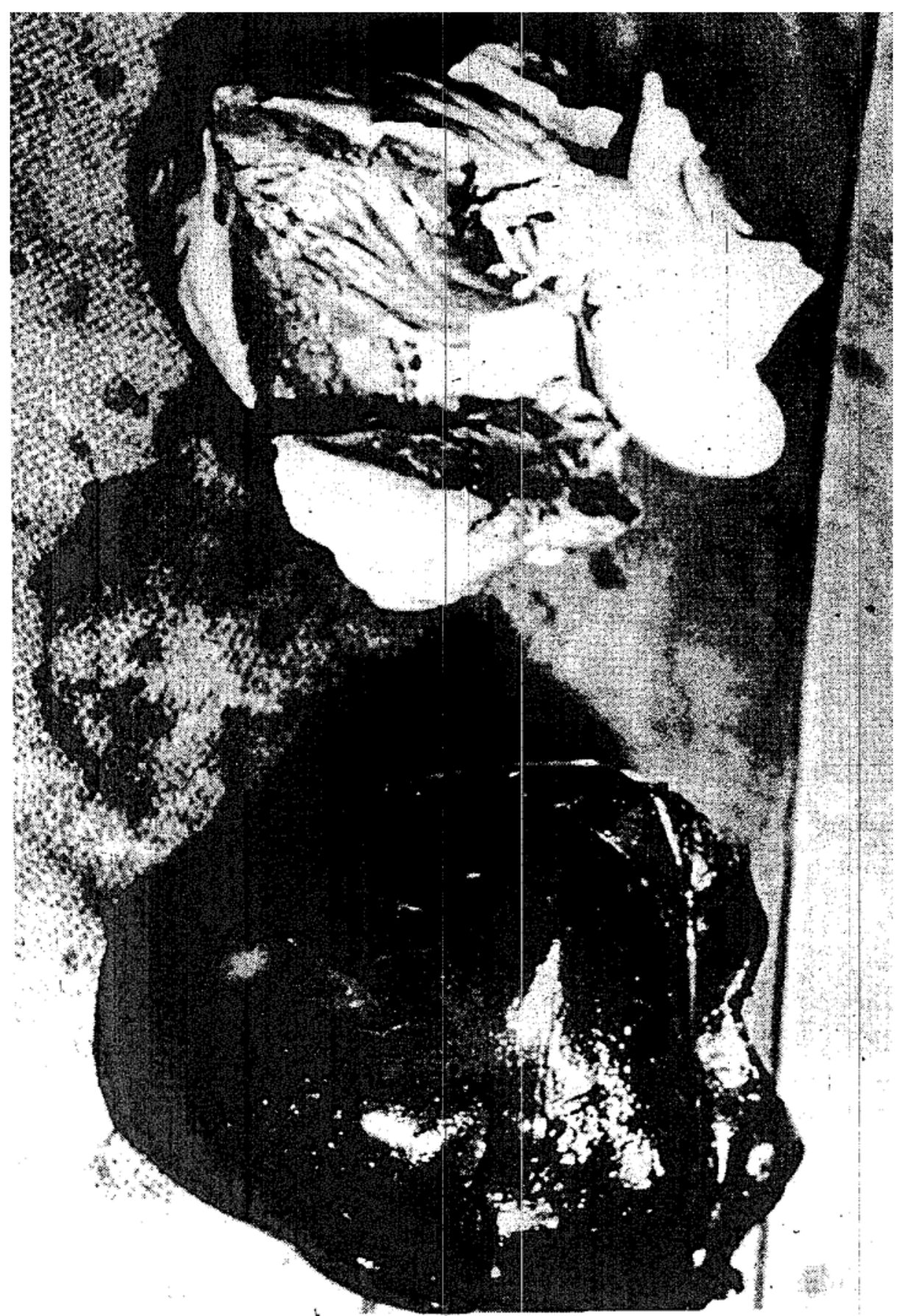

Figure 2. Cast of haemopericardiuna in relation to the heart.

patient's best interests to accept the potential operative, risks to provide her with early mobilization. The alternatives were manual reduction of the fracture, with or without application of a plaster or, after several weeks of conservative management, the use of a femoral prosthesis. Perhaps it is useful to reflect upon why the infarcted area ruptured in the recovery room and not during the surgical procedure. Slight airway obstruction with insidious hypercarbia and hypoxia 


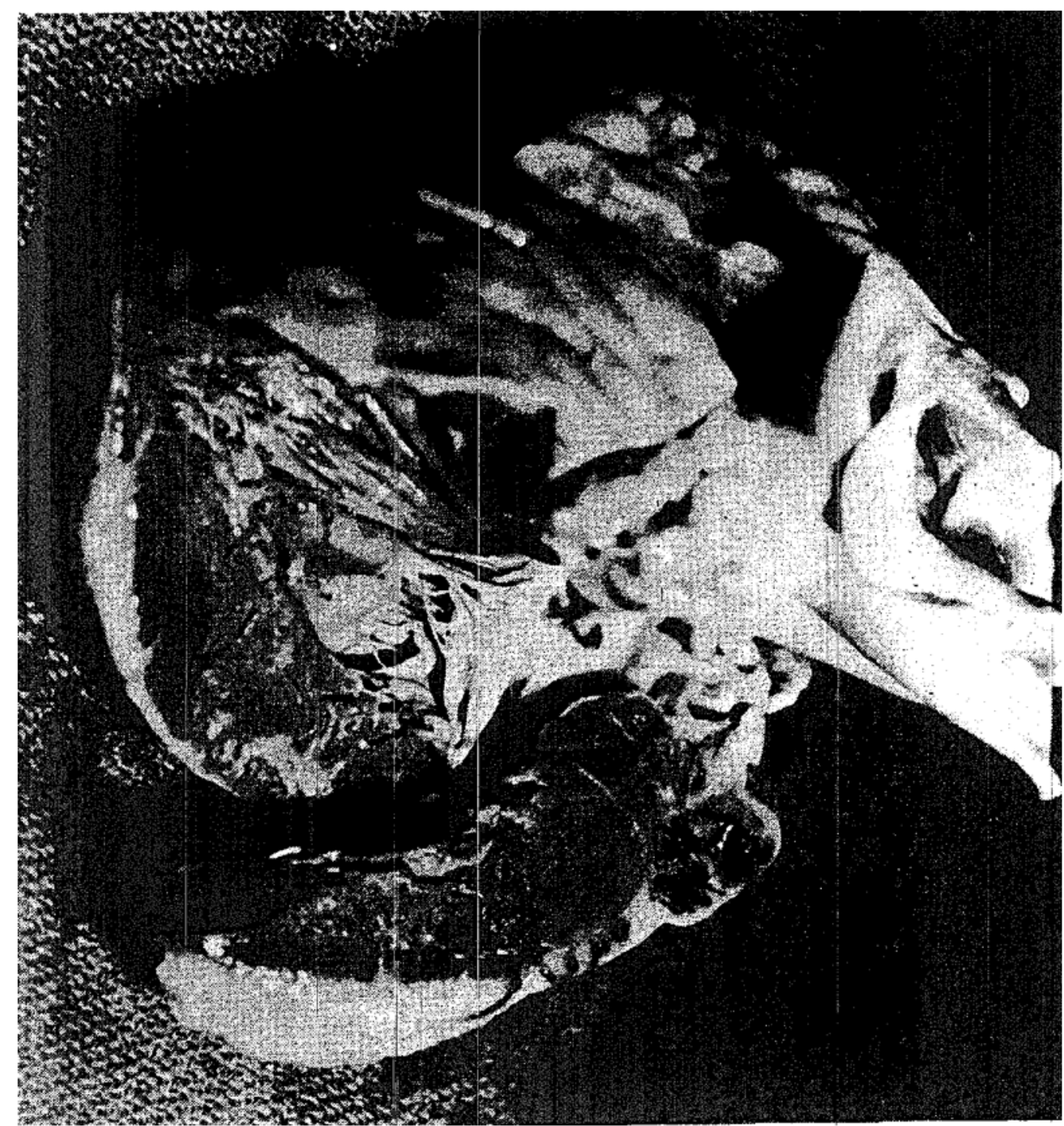

FIgure 3. The heart, showing trupture through recent anterior infarction and scar from an old posterior infarction.

are more prone to occur shortly after extubation. It is worth while to stress to recovery room staff that in dealing with poor-risk patients we must not lessen our vigilance upon completion of the operation. Indeed this must be the point from which vigorous efforts are made to protect the cardiopulmonary systems from additional stress. The hazards inherent in the decision were so clearly unfolded and documented that it was decided to present this case. The importance of a carefully conducted autopsy in elucidating the final events is clearly shown.

\section{SUMMary}

The pathology of a myocardial infarction is reviewed and the potential danger of a situation of stress during the acute phase is emphasized. The case report of a fracture of the hip in a patient who had suffered a recent myocardial in- 
farction is presented. The sequence of events and underlying pathology are demonstrated by the autopsy findings.

\section{RÉSUMÉ}

Chez les porteurs de pathologie cardiaque, le risque lanesthésique est un peu plus grand que chez les malades non cardiaques. Toutefois, la situation devient considérablement changée s'il s'agit de malades qui ont suffert d'un infarctus récent du myocarde et, parmi un groupe, le pourcentage des porteurs de'cette pathologie a atteint 18.2 pour cent. Chez le porteur d'infarctus aigu du myocarde, le stress de la chirurgie et de l'anesthésie peut conduire à la rupture de la zone infarcie et à' une tamponade cardiaque fatale. L'auteur raconte l'association infortunée d'une fracture de hanche et d'un infarctus récent du myocarde chez une vieillarde. Le malade est mort 20 minutes après son retour à la salle de réveil et, à l'autopsie, le péricarde contenait environ 280 grammes de sang frais coagulé, et il existait une déchirure à la face antérieure du ventricule gauche.

\section{ACKNOWLEDGMENTS}

We wish to thank Doctor J. Wilson and Doctor G. Glennie for permission to publish this case, Doctor R. Malone for the autopsy findings, and Doctor H. T. Norry and Mr. Hans Harsh for the photographs.

\section{REFERENCES}

1. Moseley, H. F. Textbook of Surgery, 2nd ed., p. 961. St. Louis: C. V. Mosby Co. (1952).

2. Etsten, B. \& Proger, S. J.A.M.A. 159: 845 (1955).

3. Levine, S. A. Clinical Heart Disease, 4th ed., p. 126. Philadelphia and London: W. B. Saunders Co. (1951).

4. Lee, J. A. A Synopsis of Anaesthesia, 4th ed., p. 456. Bristol: John Wright and Sons Ltd. (1959)

5. Robins, S. L. Textbook of Pathology, 1st ed., p. 483. Philadelphia and London: W. B. Saunders Co. (1957).

6. Roвins, S. L. Textbook of Pathology, 1st ed. Philadelphia and London: W. B. Saunders Co. $(1957)$. 